\title{
Review of the efficacy and safety of radiofrequency ablation for the treatment of small renal masses
}

\author{
Regina El Dib, PhD; ${ }^{*}$ Naji J. Touma, MD, FRCSC; ${ }^{\dagger}$ Anil Kapoor, MD, FRCSC ${ }^{\ddagger}$
}

\begin{abstract}
Background: Small renal masses are increasingly being discovered incidentally on imaging performed for another reason. The standard of care for these masses involves excision by open or laparoscopic techniques. Recently, ablative techniques such as radiofrequency ablation (RFA) and cryoablation have taken a more prominent role in the treatment algorithm for these masses. We sought to evaluate the efficacy and safety of radiofrequency ablation in the treatment of renal tumours.
\end{abstract}

Methods: We conducted a review of the literature. There was no language restriction. We obtained studies from the following sources: the Cochrane Library, PubMed, EMBASE, LILACS and Current Controlled Trials.

Results: We identified no clinical trials in the literature. Thus we described the results from case series and retrospective studies with a reasonable sample size (number of reported patients in each study $>65$ ). Most patients undergoing RFA had T1 a disease with a mean tumour size of about $3 \mathrm{~cm}$. Radiofrequency ablation was usually performed percutaneously with image guidance. Reported follow-up was short and ranged from 1 to 30 months. Most series used radiographic response as a surrogate for cancer control. The rates of local recurrence of the tumour were as high as $13.0 \%$ (average $8.5 \%$ ) and were slightly higher than those associated with cryoablation and partial nephrectomy. Complications included hemorrhage, ureteral strictures and loss of a renal unit.

Conclusion: Our review demonstrates that RFA is a suitable and promising therapy in patients with small renal tumours who are considered to be poor candidates for more involved surgery. However, clinical trials with long-term data are needed to establish the oncological efficacy.

Can Urol Assoc J 2009;3(2):143-9

\section{Résumé}

Contexte : De petites masses rénales sont de plus en plus souvent découvertes de façon fortuite lors d'épreuves d'imagerie commandées pour une autre raison. Les soins standard pour ces masses incluent une excision par chirurgie ouverte ou par laparoscopie. Dernièrement, des techniques comme l'ablation par radiofréquence (ARF) et la cryoablation ont pris plus d'importance dans l'algorithme de traitement. Nous examinons l'efficacité et l'innocuité de l'ablation par radiofréquence dans le traitement des tumeurs rénales.
Méthodologie : Une revue de la littérature a été effectuée, sans restriction de langue. Des articles ont été obtenus des sources suivantes : la Bibliothèque Cochrane, PUBMED, EMBASE, LILACS et Current Controlled Trials.

Résultats : Comme aucun essai clinique n'a pu être cerné dans ces bases de données, nous décrivons les résultats d'études de cas et $\mathrm{d}^{\prime}$ analyses rétrospectives avec populations de taille raisonnable (nombre de patients pour chaque étude > 65). La vaste majorité des patients ayant subi une ARF présentaient une tumeur T1a de taille moyenne d'environ $3 \mathrm{~cm}$. L'ARF était habituellement effectuée par voie percutanée et guidée par imagerie. Le suivi était court, allant de 1 à 30 mois. La plupart des études sérielles avaient recours à la réponse radiographique comme paramètre de substitution de la maîtrise du cancer. Les taux de récidive locale de la tumeur atteignaient $13.0 \%$ (moyenne $8.5 \%$ ), et étaient en général légèrement plus élevés que les taux notés avec la cryoablation et la néphrectomie partielle. Les complications signalées étaient les suivantes : hémorragie, sténose urétérale et perte d'une unité rénale. Conclusion : Le présent article montre que I'ARF est une technique convenable et prometteuse chez les patients porteurs de petites tumeurs rénales considérés comme de mauvais candidats pour une intervention plus lourde. Cependant, il est impératif d'effectuer des essais cliniques à long terme afin d'établir dans un avenir rapproché l'efficacité oncologique de cette technique.

\section{Introduction}

In Canada, the incidence of renal cancer is 4500 new cases per year, with 1500 patients dying of the disease. ${ }^{1}$ Small renal masses are increasingly being discovered incidentally on imaging performed for another reason. ${ }^{2-4}$ The natural history of these incidentally discovered masses remains unclear. When surgically excised, $70 \%-80 \%$ are proven to be renal cell carcinomas and the rest are benign..$^{5-8}$

When technically feasible, the standard of care for these masses has been partial nephrectomy. Local and distant oncological control has been well established with surgical excision. ${ }^{9}$ In the last 10 years, a minimally invasive approach with laparoscopy has largely supplanted open surgery. The question of whether in situ ablative technologies ${ }^{10,11}$ can replace excision for the treatment of small renal tumours remains unanswered. The reported advantages of ablative approaches over extirpative techniques include reduction 
El Dib et al.

of perioperative morbidity, shorter hospital stay and faster recovery time. The main advantage of ablative techniques, however, would be to offer treatment to patients who are otherwise not candidates for invasive extirpative techniques. ${ }^{12,13}$

Several ablative technologies have been investigated, including cryoablation (CA), radiofrequency ablation (RFA), microwave, ${ }^{14}$ high-intensity focused ultrasonography, ${ }^{15,16}$ laser interstitial thermotherapy, ${ }_{17}^{17}$ microwave thermotherapy and radiosurgery.

Radiofrequency ablation is a minimally invasive treatment for localized cancer in which a small needle attached to a device that delivers radiofrequency energy is inserted into a tumour to destroy the cancerous tissue while the patient is sedated or under general anesthesia. The procedure is usually performed percutaneously with image guidance using computed tomography (CT) or ultrasonography and the tumour is destroyed by heating to temperatures exceeding $60^{\circ} \mathrm{C} . .^{18}$

Radiofrequency ablation has been licensed by Health Canada and used for many years in the treatment of cardiac abnormalities, trigeminal neuralgia and osteoid osteomas; more recently, it has been used in the treatment of neoplasms in the liver, kidney, prostate, bone and soft tissues, and other areas. ${ }^{19}$ The role of RFA in the treatment of renal neoplasms is still being investigated with several series reporting short-term outcomes.

We sought to examine the state of knowledge of RFA in the treatment of renal tumours. We reviewed the efficacy of this technology in terms of oncological control and prevention of local recurrence and metastasis. We also examined complications and safety concerns as they relate to RFA.

\section{Methods}

There was no language restriction. We obtained studies from the following sources: Cochrane Central Register of Controlled Trials (Central, The Cochrane Library, issue 3, 2008), US National Library of Medicine (PubMed; 1966-2008), Excerpta Medica database (EMBASE; 1980-2008), Literatura LatinoAmericana e do Caribe em Ciências da Saúde (LILACS; 1982-2008) and Current Controlled Trials to identify all studies about RFA in patients with renal cell carcinomas.

We searched the databases using a comprehensive search strategy for kidney cancer and RFA using medical subject headings (MeSH) and key words, including an exhaustive list of synonyms (Appendix 1). We adapted the search strategy for each database to achieve more sensitivity. We also examined the bibliographic references in relevant review articles for eligible trials.

We were interested in the following clinical outcome measurements: cancer specific survival, radiographic success, tumour recurrence, local tumour progression or distant metastases, need for repeat ablation, complications, adverse events reported and renal function.

\section{Results}

Our search in the electronic databases identified 1428 titles. After screening by title and then abstract, we obtained full paper copies for 71 studies that were potentially eligible for inclusion in the review. Of these, we did not identify any randomized controlled trials. We identified several case series and retrospective studies and 1 controlled clinical trial. Thus we included the case series and retrospective studies with a reasonable sample size $(n>65)$, and the controlled clinical trial in our review.

Table 1 summarizes the characteristics of published studies on RFA. Most patients undergoing RFA had T1a disease with a mean tumour size of about $3 \mathrm{~cm}$. RFA was usually carried out percutaneously with image guidance. However, if the tumour was endophytic or otherwise not accessible percutaneously, laparoscopy could be carried out to expose the kidney and the tumour. Reported follow-up was short and ranged from 1 to 30 months.

Table 2 outlines the clinical outcomes and complications reported in the RFA studies we examined. Most series used radiographic response as a surrogate for cancer control. We considered lack of contrast enhancement, decrease in size of the tumour or lack of growth on serial imaging to be signs of complete and successful ablation. The rates of local recurrence of the tumour were as high as $13.0 \%$ (average $8.5 \%$ ) and were slightly higher than those associated with cryoablation and partial nephrectomy.

Although RFA is generally well tolerated with a favourable complication profile, it is not an innocuous procedure. Serious complications can occur, including hemorrhage, ureteral strictures and loss of a renal unit. 


\section{Discussion}

The goal of RFA is to destroy tissue by heat using radiofrequency energy. The procedure involves delivering an alternating electrical current at high frequency causing agitation of ions, which in turn results in heat. It has been shown that heating tissue to $55^{\circ}-60^{\circ} \mathrm{C}$ for 5 minutes results in irreversible

Table 1. Noncontrolled, controlled and retrospective studies on radiofrequency ablation for renal tumours

\begin{tabular}{|c|c|c|c|c|c|c|c|c|c|}
\hline Study & Design & $\begin{array}{c}\text { Comparative } \\
\text { group(s) }\end{array}$ & $\begin{array}{c}\text { No. of } \\
\text { patients }\end{array}$ & $\begin{array}{c}\text { No. of } \\
\text { tumours }\end{array}$ & $\begin{array}{c}\text { Mean tumour } \\
\text { size or range, } \\
\mathrm{cm}\end{array}$ & Exophytic & $\begin{array}{l}\text { Parenchymal, } \\
\text { central or } \\
\text { mixed }\end{array}$ & $\begin{array}{l}\text { Type of } \\
\text { RFA }\end{array}$ & $\begin{array}{c}\text { Follow-up, } \\
\text { mo }\end{array}$ \\
\hline $\begin{array}{l}\text { Ganguli } \\
\text { et al. }{ }^{20}\end{array}$ & $\begin{array}{l}\text { Retrospective } \\
\text { study }\end{array}$ & NA & 66 & 72 & 2.7 & 47 & 25 & Percutaneous & 1 \\
\hline $\begin{array}{l}\text { Lucas } \\
\text { et al. }\end{array}$ & $\begin{array}{l}\text { Retrospective } \\
\text { comparative } \\
\text { study }\end{array}$ & RN or PN & $\begin{array}{l}\text { RFA } 86 \\
\text { PN } 85 \\
\text { RN } 71\end{array}$ & NR & $\begin{array}{c}\text { RFA } 2.34 \\
\text { PN } 2.6 \\
\text { RN } 3.16\end{array}$ & NR & & NR & 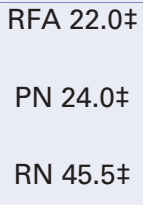 \\
\hline $\begin{array}{l}\text { Weight } \\
\text { et al. }{ }^{21}\end{array}$ & $\begin{array}{l}\text { Retrospective } \\
\text { comparative } \\
\text { study }\end{array}$ & LC & $\begin{array}{l}\text { RFA } 88 \\
\text { LC } 176\end{array}$ & $\begin{array}{c}\text { RFA } \\
109 \\
\text { LC } 192\end{array}$ & $\begin{array}{l}\text { RFA } 2.5 \\
\text { LC } 2.4\end{array}$ & NR & & Percutaneous & 6 \\
\hline $\begin{array}{l}\text { Wingo } \\
\text { and } \\
\text { Leveillee }^{22}\end{array}$ & Case series & NA & 131 & 146 & $1.0-5.3$ & 41 & 105 & $\begin{array}{c}\text { Percutaneous } \\
\text { and } \\
\text { laparoscopic }\end{array}$ & $29 \S$ \\
\hline $\begin{array}{l}\text { Bensalah } \\
\text { et al. }^{23}\end{array}$ & $\begin{array}{l}\text { Retrospective } \\
\text { comparative } \\
\text { study }\end{array}$ & $\begin{array}{c}\text { Laparoscopic } \\
\text { PN }\end{array}$ & $\begin{array}{l}\text { RFA } 38 \\
\text { LPN } 50\end{array}$ & NR & $\begin{array}{l}\text { RFA } 2.3 \\
\text { LPN } 2.6\end{array}$ & NR & & Laparoscopic & $\begin{array}{l}\text { RFA } 15 \S \\
\text { LPN } 25 \S\end{array}$ \\
\hline $\begin{array}{l}\text { Breen } \\
\text { et al. }\end{array}$ & Case series & NA & 97 & 105 & 3.2 & 86 & 19 & NR & $16.7 \S$ \\
\hline $\begin{array}{l}\text { Stern } \\
\text { et al. }^{25}\end{array}$ & $\begin{array}{l}\text { Retrospective } \\
\text { comparative } \\
\text { study }\end{array}$ & $\begin{array}{l}\text { Open or } \\
\text { laparoscopic } \\
\text { nephron- } \\
\text { sparing } \\
\text { surgery PN }\end{array}$ & $\begin{array}{l}\text { RFA } 40 \\
\text { PN } 37\end{array}$ & NR & $\begin{array}{l}\text { RFA } 2.41 \\
\text { PN } 2.43\end{array}$ & NR & & $\begin{array}{c}\text { Percutaneous } \\
\text { and } \\
\text { laparoscopic }\end{array}$ & $\begin{array}{l}\text { RFA 30§ } \\
\text { PN 47§ }\end{array}$ \\
\hline $\begin{array}{l}\text { Zagoria } \\
\text { et al. }{ }^{26 *}\end{array}$ & Case series & NA & 104 & 125 & 2.7 & 94 & 31 & Percutaneous & $13.8 \S$ \\
\hline $\begin{array}{l}\text { Hegarty } \\
\text { et al. }{ }^{27}\end{array}$ & $\begin{array}{l}\text { Retrospective } \\
\text { comparative } \\
\text { study }\end{array}$ & LC & $\begin{array}{l}\text { RFA } 72 \\
\text { LC } 161\end{array}$ & $\begin{array}{l}\text { RFA } 81 \\
\text { LC } 179\end{array}$ & $\begin{array}{c}\text { RFA } 2.51 \\
\text { LC } 2.56\end{array}$ & NR & & Percutaneous & $\begin{array}{l}\text { RFA } 12 \\
\text { LC } 36\end{array}$ \\
\hline $\begin{array}{l}\text { Matin } \\
\text { et al. }{ }^{28}\end{array}$ & $\begin{array}{l}\text { Retrospective } \\
\text { comparative } \\
\text { study }\end{array}$ & CA & $\begin{array}{c}\text { RFA } \\
410 \\
\text { CA } 206\end{array}$ & $\begin{array}{c}\text { RFA } \\
466 \\
\text { CA } 230\end{array}$ & $0.9-8.9$ & $39 \%$ & $61 \%$ & $\begin{array}{l}\text { Percutaneous } \\
\text { and } \\
\text { laparoscopic }\end{array}$ & $24.2 \S$ \\
\hline $\begin{array}{l}\text { Gervais } \\
\text { et al. }\end{array}$ & $\begin{array}{l}\text { Retrospective } \\
\text { study }\end{array}$ & NA & 85 & 100 & 3.2 & 67 & 33 & Percutaneous & 28 \\
\hline $\begin{array}{l}\text { Matsumoto } \\
\text { et al. }{ }^{30} \dagger\end{array}$ & $\begin{array}{l}\text { Retrospective } \\
\text { study }\end{array}$ & NA & 91 & 109 & 2.4 & NR & & $\begin{array}{c}\text { Percutaneous } \\
\text { and } \\
\text { laparoscopic }\end{array}$ & 19 \\
\hline $\begin{array}{l}\text { Wah } \\
\text { et al. }\end{array}$ & $\begin{array}{l}\text { Controlled } \\
\text { clinical trial }\end{array}$ & $\begin{array}{l}\text { CG (biopsy } \\
\text { of focal } \\
\text { renal } \\
\text { lesions) }\end{array}$ & $\begin{array}{l}\text { RFA } 17 \\
\text { CG } 20\end{array}$ & $\begin{array}{l}\text { RFA } 11 \\
\text { CG NR }\end{array}$ & 3.1 & NR & & Percutaneous & \\
\hline $\begin{array}{l}\text { DiMarco } \\
\text { et al. }^{32}\end{array}$ & Case series & NA & 66 & 91 & 2.0 & 53 & 38 & NR & $9.0 \S$ \\
\hline \multicolumn{10}{|c|}{$\begin{array}{l}\text { CA = cryoablation; } C G=\text { control group; } L C=\text { laparoscopic cryoablation; } L P N=\text { laparoscopic par } \\
\text { nephrectomy; } R F A=\text { radiofrequency ablation; } R N=\text { radical nephrectomy. } \\
\text { *Uzzo } 2007 \text { study is a duplicate publication of Zagoria et al. }{ }^{34} \\
\text { †A } 2006 \text { study by Park has the same participants as the study by Matsumoto and colleagues. }{ }^{23} \\
\text { ‡Median. } \\
\text { §Mean. }\end{array}$} \\
\hline
\end{tabular}


El Dib et al.

cellular damage, and heating to more than $70^{\circ} \mathrm{C}$ causes cell death and tissue coagulation..$^{33,34}$ Temperature-based RFA machines (e.g., RITA Medical Systems, Inc.) use temperatures as high as $105^{\circ} \mathrm{C}$ during treatment. One drawback to RFA is that, unlike cryoablation, it is not possible to monitor the ablated area via imaging in real time. It is therefore difficult to ensure that the entire surface area of a tumour receives the same amount of heat.

Our review demonstrates that although promising, the evidence behind RFA remains immature. Prospective and randomized trials are lacking. Reported follow-up is too short, with most studies reporting a follow-up of 2 years or less and all studies reporting a follow-up less than 3 years. The natural history of small renal masses is not well defined, but one review demonstrated a growth rate of $0.28 \mathrm{~cm} /$ year with a metastatic rate of $1 \%$ after 34 months of follow-up. ${ }^{35}$ This seems to indicate that the reported follow-up for most RFA series is too short to draw any meaningful conclusions about oncological efficacy.

Most RFA studies equate a successful ablation with radiological response. However, imaging changes after RFA are not always predictable. Tumours ablated with RFA do not consistently

Table 2. Clinical outcomes and complications of each included study (part 1 of 2)

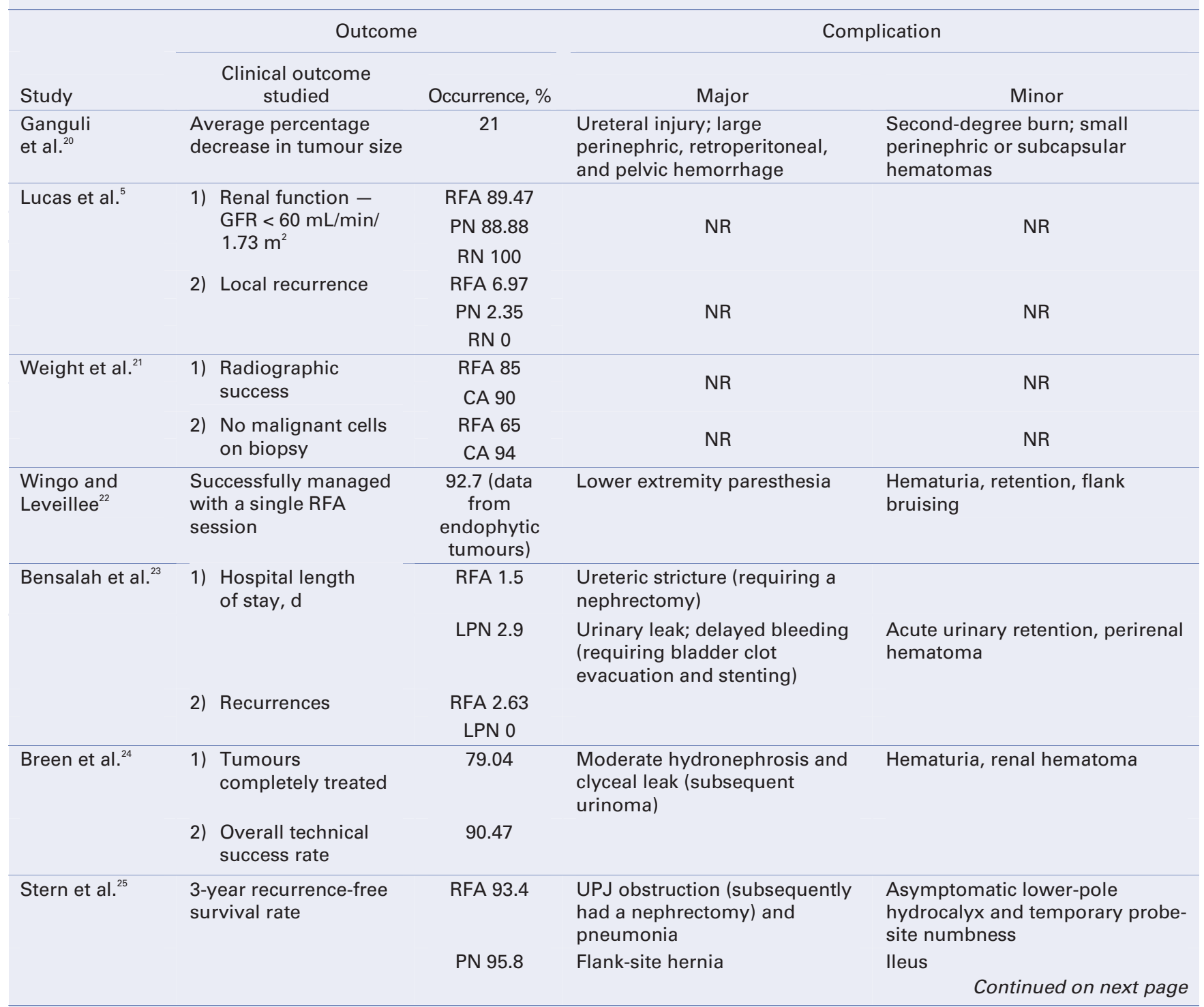


regress in size. In addition, a peritumour halo may form with fat infiltration. Successfully treated tumours do usually demonstrate a lack of enhancement on CT scans. ${ }^{30}$ It remains unclear whether radiological response is an adequate surrogate for cancer control. Histopathological confirmation of complete ablation is also not completely reliable owing to sampling error and the high falsenegative rate of percutaneous biopsies. ${ }^{36}$ Three studies performed a complete histopathological examination of tumours treated with RFA after either a radical or partial nephrectomy. Rendon and colleagues $^{37}$ found persistent cancer in
$5 \%-10 \%$ of tumour volume. Matlaga and colleagues ${ }^{38}$ found 2 of 10 tumours to be incompletely ablated, and Michaels and colleagues ${ }^{39}$ found 4 of 5 tumours to be incompletely ablated.

\section{Conclusion}

This review demonstrates that RFA is a suitable and promising therapy in patients with small renal tumours $(<4 \mathrm{~cm})$ who are considered to be poor candidates for more involved surgery. Long-term data on oncological control is lacking. Longer follow-up and more rigorous head-to-head trials

Table 2. Clinical outcomes and complications of each included study (part 2 of 2)

\begin{tabular}{|c|c|c|c|c|}
\hline \multirow[b]{2}{*}{ Study } & \multicolumn{2}{|l|}{ Outcome } & \multicolumn{2}{|c|}{ Complication } \\
\hline & $\begin{array}{c}\text { Clinical outcome } \\
\text { studied }\end{array}$ & Occurrence, \% & Major & Minor \\
\hline Zagoria et al. ${ }^{26}$ & $\begin{array}{l}\text { Completely ablated } \\
\text { tumour }\end{array}$ & 93 & $\begin{array}{l}\text { Large perinephric hematoma; } \\
\text { pneumonia; severe neuropathic } \\
\text { pain and ureteral strictures with } \\
\text { concomitant hydronephrosis }\end{array}$ & $\begin{array}{l}\text { Small pneumothoraces, perirenal } \\
\text { hemorrhage, apnea, tachycardia, } \\
\text { flank pain }\end{array}$ \\
\hline \multirow[t]{3}{*}{ Hegarty et al. ${ }^{27}$} & \multirow[t]{2}{*}{$\begin{array}{l}\text { 1) Radiological evidence } \\
\text { of tumour recurrence } \\
\text { or persistence of } \\
\text { disease }\end{array}$} & RFA11.1 & $\begin{array}{l}\text { There were no major } \\
\text { complications }\end{array}$ & $\begin{array}{l}\text { Perirenal hematoma; } \\
\text { retroperitoneal hematoma; } \\
\text { perirenal abscess and upper pole } \\
\text { hydrocalicosis }\end{array}$ \\
\hline & & CA 1.8 & $\begin{array}{l}\text { Myocardial infarction; } \\
\text { congestive heart failure and } \\
\text { hemothorax }\end{array}$ & $\begin{array}{l}\text { Urine leak; obstructed solitary } \\
\text { kidney; pneumothorax; perirenal } \\
\text { fluid collection and blood } \\
\text { transfusion }\end{array}$ \\
\hline & $\begin{array}{l}\text { 2) Cancer-specific } \\
\text { survival }\end{array}$ & $\begin{array}{l}\text { RFA } 100 \\
\text { CA } 98\end{array}$ & & \\
\hline \multirow[t]{2}{*}{ Matin et al. ${ }^{28}$} & \multirow{2}{*}{$\begin{array}{l}\text { Overall residual or } \\
\text { recurrent disease }\end{array}$} & RFA 13.4 & NR & NR \\
\hline & & CA 3.9 & NR & NR \\
\hline Gervais et al. ${ }^{29}$ & $\begin{array}{l}\text { Complete tumour } \\
\text { necrosis by imaging } \\
\text { criteria }\end{array}$ & 90 & $\begin{array}{l}\text { Hemorrhage requiring RBC } \\
\text { transfusion and stent } \\
\text { placement; asymptomatic } \\
\text { posterior abdominal wall } \\
\text { enhancing mass; ureteral } \\
\text { stricture; urinoma and ureteral } \\
\text { injury }\end{array}$ & $\begin{array}{l}\text { Hemorrhage not requiring } \\
\text { transfusion; inflammatory track } \\
\text { mass; skin burns and transient } \\
\text { neuropathic pain }\end{array}$ \\
\hline $\begin{array}{l}\text { Matsumoto } \\
\text { et al. }\end{array}$ & $\begin{array}{l}\text { Successful ablation of } \\
\text { the tumour }\end{array}$ & 98 & $\begin{array}{l}\text { Lower-pole infarct, urine leak } \\
\text { and UPJ obstruction }\end{array}$ & $\begin{array}{l}\text { Leg and arm neuropathy; } \\
\text { pneumonia; prolonged pain; } \\
\text { postoperative narcotic reaction } \\
\text { and hydrocalix }\end{array}$ \\
\hline \multirow[t]{2}{*}{ Wah et al. ${ }^{31}$} & $\begin{array}{l}\text { Occurrence of fever } \\
\text { and flulike symptoms }\end{array}$ & RFA 82 & $\begin{array}{l}\text { Flu-like symptoms; pneumonia; } \\
\text { pain; }\end{array}$ & $\begin{array}{l}\text { Lifestyle interference with } \\
\text { general activities and work } \\
\text { activities }\end{array}$ \\
\hline & & CG NR & & \\
\hline DiMarco et al. $^{32}$ & $\begin{array}{l}\text { Successful ablation of } \\
\text { the tumour }\end{array}$ & 95 & $\begin{array}{l}\text { UPJ obstruction; chronic } \\
\text { lumbar plexopathy pain; } \\
\text { wedge shaped renal infarct; } \\
\text { major hemorrhage }\end{array}$ & NR \\
\hline
\end{tabular}


El Dib et al.

are needed to determine the exact role of RFA in the treatment algorithm of small renal masses.

*Post-doctoral Urology Fellow, St. Joseph's Healthcare, McMaster University, Hamilton, Ont., †Clinical Laparoscopy and Endourology Fellow, St. Joseph's Healthcare, McMaster University, Hamilton, Ont., ‡Renal Transplant Program Surgical Director, Urologic Laparoscopy Program Director and Associate Professor of Surgery (Urology), St. Joseph's Healthcare, McMaster University, Hamilton, Ont.

This article has been peer reviewed.

Competing interests: None declared.

\section{References}

1. Canadian cancer statistics 2005. Toronto: Canadian Cancer Society, National Cancer Institute of Canada, Public Health Agency of Canada; 2005. Available: www.cancer .ca/Canada-wide/Publications/Publications\%20on\%20cancer\%20statistics/ /media /CCS/Canada\%20wide/Files\%20list/English\%20files\%20heading/pdf\%20not\%20in\% 20publications\%20section/Canadian\%20Cancer\%20Statistics\%20-\%202005\%20 -\%20EN\%20-\%20PDF_401594768.ashx (accessed 2009 Feb 27).

2. Pantuck AJ, Zisman A, Belldegrun AS. The changing natural history of renal cell carcinoma. J Urol 2001;166:1611-23.

3. Chow WH, Devesa SS, Warren JL, et al. Rising incidence of renal cell cancer in the United States. JAMA 1999;281:1628-31.

4. Wunderlich H, Schumann S, Jantitzky V, et al. Increase of renal cell carcinoma incidence in central Europe. Eur Urol 1998;33:538-41.

5. Lucas SM, Stern JM, Adibi $M$, et al. Renal function outcomes in patients treated for renal masses smaller than $4 \mathrm{~cm}$ by ablative and extirpative techniques. J Urol 2008; 179:75-80.

6. Asano T, Mizuguchi Y, Horiguchi A, et al. Retroperitoneoscopic partial nephrectomy using radiofrequency coagulation for small renal tumors. Urology 2007;70:869-72.

7. Devoe WB, Kercher KW, Hope WW, et al. Hand-assisted laparoscopic partial nephrectomy after 60 cases: comparison with open partial nephrectomy. Surg Endosc 2008 Oct. 2 [Epub ahead of print].

8. Pyo P, Chen A, Grasso M. Retroperitoneal laparoscopic partial nephrectomy: surgical experience and outcomes. J Urol 2008;180:1279-83.

9. Desai PJ, Andrews PE, Ferrigni RG, et al. Laparoscopic partial nephrectomy at the Mayo Clinic Arizona: follow-up surveillance of positive margin disease. Urology 2007;71: 283-6.

10. Pavlovich CP, Walther MM, Choyke PL, et al. Percutaneous radio frequency ablation of small renal tumours: initial results. J Urol 2002;167:10-5.

11. Gill IS, Novick AC, Soble JJ, et al. Laparoscopic renal cryoablation: initial clinical series. Urology 1998;52:543-51.

12. Raj GV, Reddan DJ, Hoey MF, et al. Management of small renal tumors with radiofrequency ablation. Urology 2003;61:23-9.

13. Shingleton WB, Sewell PE. Percutaneous renal tumor cryoablation with magnetic resonance imaging guidance. J Urol 2001;165:773-6.

14. Yoshimura K, Okubo K, Ichioka K, et al. Laparoscopic partial nephrectomy with a microwave tissue coagulator for small renal tumor. J Urol 2001;165:1893-6.

15. Vallancien G, Chartier-Kastler E, Chopin D, et al. Focused extracorporeal pyrotherapy: experimental results. Eur Urol 1991;20:211-9.

16. Watkin NA, Morris SB, Rivens IH, et al. High-intensity focused ultrasound ablation of the kidney in a large animal model. J Endourol 1997;11:191-6.

17. Lotfi MA, McCue P, Gomella LG. Laparoscopic interstitial contact laser ablation of renal lesions: an experimental model. J Endourol 1994;8:153-6.

18. The National Institute for Health and Clinical Excellence (NICE). Percutaneous radio- frequency ablation of renal cancer. London (UK): The Institute; 2004. Available: www.nice.org.uk/ip215overview (accessed 2009 Feb 27).

19. Wood BJ, Ramkaransingh JR, Fojo $\mathrm{T}$, et al. Percutaneous tumor ablation with radiofrequency. Cancer 2002;94:443-51.

20. Ganguli S, Brennan DD, Faintuch $S$, et al. Immediate renal tumor involution after radiofrequency thermal ablation. J Vasc Interv Radiol 2008;19:412-8.

21. Weight CJ, Kaouk JH, Hegarty NJ, et al. Correlation of radiographic imaging and histopathology following cryoablation and radio frequency ablation for renal tumors. J Urol 2008;179:1277-83.

22. Wingo MS, Leveillee RJ. Central and deep renal tumors can be effectively ablated: radiofrequency ablation outcomes with fiberoptic peripheral temperature monitoring. J Endourol 2008;22:1261-7.

23. Bensalah K, Zeltser I, Tuncel A, et al. Evaluation of costs and morbidity associated with laparoscopic radiofrequency ablation and laparoscopic partial nephrectomy for treating small renal tumours. BJU Int 2007;101:467-71.

24. Breen DJ, Rutherford EE, Stedman B, et al. Management of renal tumors by imageguided radiofrequency ablation: experience in 105 tumors. Cardiovasc Intervent Radiol 2007;30:936-42

25. Stern JM, Svatek R, Park $S$, et al. Intermediate comparison of partial nephrectomy and radiofrequency ablation for clinical Tla renal tumours. BJU Int 2007;100:287-90.

26. Zagoria RJ, Traver MA, Werle DM, et al. Oncologic efficacy of CT-guided percutaneous radiofrequency ablation of renal cell carcinomas. AJR Am J Roentgenol 2007; 189:429-36

27. Hegarty NJ, Gill IS, Desai MM, et al. Probe-ablative nephron-sparing surgery: cryoablation versus radiofrequency ablation. Urology 2006;68(Suppl):7-13.

28. Matin SF, Ahrar K, Cadeddu JA, et al. Residual and recurrent disease following renal energy ablative therapy: a multi-institutional study. J Urol 2006;176:1973-7.

29. Gervais DA, McGovern FJ, Arellano RS, et al. Radiofrequency ablation of renal cell carcinoma: part 1, Indications, results, and role in patient management over a 6-year period and ablation of 100 tumors. AJR Am J Roentgenol 2005;185:64-71.

30. Matsumoto ED, Johnson DB, Ogan K, et al. Short-term efficacy of temperature-based radiofrequency ablation of small renal tumors. Urology 2005;65:877-81.

31. Wah TM, Arellano RS, Gervais DA, et al. Image-guided percutaneous radiofrequency ablation and incidence of post-radiofrequency ablation syndrome: prospective survey. Radiology 2005;237:1097-102.

32. DiMarco DS, Farrell MA, Zincke H, et al. Radiofrequency ablation of renal tumors. J Urol 2004;171:129.

33. Patterson EJ, Scudamore CH, Owen DA, et al. Radiofrequency ablation of porcine liver in vivo: effects of blood flow and treatment time on lesion size. Ann Surg 1998;227:559-65

34. Scudamore CH, Lee SI, Patterson EJ, et al. Radiofrequency ablation followed by resection of malignant liver tumors. Am J Surg 1999;177:411-7.

35. Chawla SN, Crispen PL, Hanlon AL, et al. The natural history of observed enhancing renal masses: meta-analysis and review of the world literature. J Urol 2006;175:425-31.

36. Permpongkosol S, Link RE, Solomon SB, et al. Results of computerized tomography guided percutaneous ablation of renal masses with nondiagnostic pre-ablation pathological findings. J Urol 2006;176:463-7.

37. Rendon RA, Kachura JR, Sweet JM, et al. The uncertainty of radio frequency treatment of renal cell carcinoma: findings at immediate and delayed nephrectomy. J Urol 2002;167:1587-92

38. Matlaga BR, Zagoria RJ, Woodruff RD, et al. Phase II trial of radio frequency ablation of renal cancer: evaluation of the kill zone. J Urol 2002;168:2401-5.

39. Michaels MJ, Rhee HK, Mourtzinos AP, et al. Incomplete renal tumor destruction using radio frequency interstitial ablation. J Urol 2002; 168:2406-9.

Correspondence: Dr. Anil Kapoor, McMaster Institute of Urology, McMaster University, St. Joseph's Healthcare, 50 Charlton Ave. E., Hamilton ON L8N 4A6; kapoor4@mcmaster.ca 
Appendix 1. Summary of the bibliographic search strategies for type of clinical situation and intervention of interest

((Kidney Neoplasm) OR (Renal Neoplasms) OR (Renal Neoplasm) OR (Kidney Neoplasms) OR (Cancer of Kidney) OR (Kidney Cancers) OR (Renal Cancer) OR (Renal Cancers) OR (Cancer of the Kidney) OR (Kidney Cancer) OR (Kidney Cancers) OR (Renal masses) OR (Renal cell carcinoma)) AND ((Radiofrequency ablation) OR (Catheter ablation) OR (Electric Catheter Ablation) OR (Electrical Catheter Ablation) OR (Radiofrequency Catheter Ablation) OR (Transvenous Catheter Ablation) OR (Transvenous Electric Ablation) OR (Transvenous Electrical Ablation) OR (Percutaneous Catheter Ablation) OR (Percutaneous Radiofrequency ablation) OR (Radio frequency) OR Radio-frequency OR (Radiofrequency thermal ablation) OR (Minimally invasive therapy) OR (Tumor ablation) OR (CT-guided percutaneous radiofrequency ablation))

We welcome your comments on the journal and on specific articles.

\author{
All letters will be considered \\ for publication in the journal.
}

CUAJ JAUC

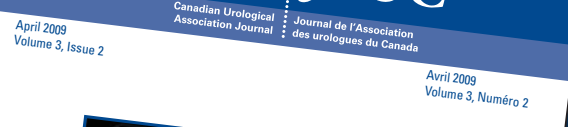

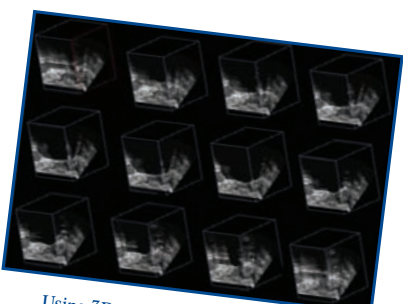

Using 3D ultrasonography to monitor cyrotherapy

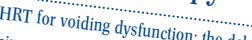
Examining a granular cell tumour ine debate How does treatment delumour involving the ureter and survival?

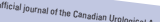
journal@cua.org 